\title{
An Empirical Examination of the Determinants of Foreign Direct Investment: A Firm-Level Analysis for the Colombian Economy*
}

\author{
Received: November 19, 2013 - Accepted for publication: March 13, 2014 \\ Doi: dx.doi.org/10.12804/rev.econ.rosario.17.01.2014.01
}

\author{
Aarón Garavito ${ }^{\dagger}$ \\ Banco de la República, Colombia \\ Ana María Iregui $\ddagger$ \\ Banco de la República, Colombia \\ María Teresa Ramírez $\$$ \\ Banco de la República, Colombia
}

* We want to thank Jesús Otero, Carlos Pombo and Héctor Zárate for their comments and suggestions. We also wish to thank Carmen Cecilia Delgado, Laura García and Erika Londoño for their excellent research assistance. The opinions expressed here in are those of the authors and do not necessarily reflect the views of Banco de la República or its Board of Directors.

+ Senior Economist, Economic Studies Department, Banco de la República, Carrera 7 \# 14-78 Piso 11, Bogotá, Colombia. E-mail: agaravac@banrep.gov.co

‡ Senior Researcher, Research Unit, Banco de la República, Carrera 7 \# 14-78 Piso 11, Bogotá, Colombia. E-mail: airegubo@banrep.gov.co

§ Senior Researcher, Research Unit, Banco de la República, Carrera 7 \# 14-78 Piso 11, Bogotá, Colombia. E-mail: mramirgi@banrep.gov.co

To cite this article: Garavito, A., Iregui, A. M., \& Ramírez, M. T. (2014). An Empirical Examination of the Determinants of Foreign Direct Investment: A Firm-Level Analysis for the Colombian Economy. Revista de Economía del Rosario, 17(1), 5-31. doi: dx.doi.org/10.12804/rev. econ.rosario.17.01.2014.01 


\begin{abstract}
We use a large firm level data set to investigate the determinants of foreign direct investment (FDI) in Colombia. We estimate econometric models for the determinants of the probability that a firm receives FDI, as well as for the factors that help to explain the foreign share in a firm's capital. The results show that firms listed on the stock market, involved in foreign trade activities, and operating in sectors with greater capital intensity are more likely to be recipients of FDI. Also, the probability of a firm receiving FDI is directly related to its size.
\end{abstract}

JEL classification: C23, C25, F20, F21.

Key words: foreign direct investment (FDI), panel probit, database at firm level, Colombia.

\title{
Análisis empírico de los determinantes de la inversión extranjera directa en Colombia: Evidencia a nivel de firma
}

\author{
Resumen
}

En este artículo se utiliza una base de datos a nivel de firma para investigar los determinantes de la inversión extranjera directa (IED) en Colombia. Estimamos modelos econométricos de los determinantes de la probabilidad de que una empresa reciba IED, y de los factores que explican la participación extranjera en el capital de una empresa. Los resultados indican que las firmas inscritas en bolsa, que participan en comercio exterior, y que operan en sectores con mayor intensidad de capital son las más propensas a recibir IED. Además, la probabilidad de que una empresa reciba IED está relacionada con su tamaño.

Clasificación JEL: C23, C25, F20, F21.

Palabras clave: inversión extranjera directa, panel probit, base de datos a nivel de firma, Colombia.

\section{Análise empírica dos determinantes da inversão estrangeira direta na Colômbia: Evidencia ao nível de firma}

\author{
Resumo
}

Neste artigo utiliza-se uma base de dados ao nível de firma para pesquisar os determinantes da inversão estrangeira direta (IED) na Colômbia. Estimamos modelos econométricos dos determinantes da probabilidade de que uma empresa receba IED, e dos fatores que explicam a participação estrangeira no capital de uma empresa. Os resultados indicam que as firmas inscritas na bolsa, que participam em comercio exterior, e que operam em setores com maior intensidade de capital são as mais propensas a receber IED. Além disso, a probabilidade de que uma empresa receba IED está relacionada com seu tamanho.

Classificação JEL: C23, C25, F20, F21.

Palavras-chave: inversão estrangeira direta, modelo probit, base de dados ao nível de firma, Colômbia. 


\section{Introduction}

During the last three decades or so, economic integration among countries have deepened through increased participation in world markets for capital, goods and services. In this context, transnational corporate investments have played a key role in financing new economic structures both at the regional and country levels. In particular, foreign direct investment (FDI) is essential to an economy as a source of external funding and, given the effect it can have on a country's balance of payments, long-term economic growth and productivity. Moreover, FDI helps increase the transfer of technology, capital formation, competitiveness and qualification of the local labor force, in addition to reducing a firm's costs. Taking the above considerations into account, it is relevant to analyze the economic features that make firms attractive to foreign investors.

In recent years, Colombia, like many other emerging market economies, has been a recipient of increasing inflows in the form of FDI. It has been argued that investment inflows to the various sectors of the Colombian economy have been partly the result of a regulatory framework favorable to foreign investors, as it has been designed to provide them with both stability and certainty in legal terms. ${ }^{1}$

Literature on FDI in Colombia has examined numerous subjects both at the macro and the micro levels. Focusing on the latter, topics such as the effectiveness of the regulatory framework designed to attract FDI, the relationship among foreign investment, exports and innovation, as well as among FDI, growth and productivity have been the subject of attention (see, inter alia, Steiner and Giedion (1995), Echavarria and Zodrow (2005), Atallah (2006), Kugler (2006), Kalin (2009), De Lombaerde and Garay (2009)). However, to the best of our knowledge the study of the factors that make firms more likely to receive FDI has not received enough attention. Moreover, it appears that the scarcity of this strand of the literature is not exclusive to Colombia, as it applies to other emerging economies as well.

In an attempt to contribute to the literature, the aim of this paper is to study the determinants of FDI in Colombia, for which we take advantage of a unique and large dataset at the firm level. The dataset, which has been collected by the authors, consists of annual observations over the period 2000 to 2010, and comprises more than 5.300 firms from a large spectrum of economic sectors, some of which of strategic importance for the economy as a whole (such as

1 For details on the recent evolution of Colombian FDI and its regulatory framework, see Garavito et al. (2012). 
petroleum and electricity, gas and water). An interesting feature of the dataset is that the level of disaggregation is such that we are able to examine firms of different sizes. Moreover, the dataset lends itself to analyze the characteristics of the firms that received FDI and compare them to those which did not receive it. To accomplish this objective, we perform two econometric exercises: the first one involves the specification and estimation of a model to find the factors that determine the probability that a firm is recipient of FDI; the second one focuses on a model to help explain the foreign share of the firm's capital.

Our findings suggest that firms that are more likely to attract FDI are capital intensive ones, of greater size, with well-established business structures, and that are involved in activities related to foreign trade. Interestingly, the results also show that the probability of a firm receiving FDI decreases for companies operating in economic sectors different from petroleum.

The paper is divided into four sections, in addition to the introduction. The second one reviews the economic literature on FDI. In the third section, we characterize the firms that receive FDI and compared them to those that do not receive this type of investment. In the fourth section, the results of the econometric estimations are presented. The final section offers some concluding remarks.

\section{Literature Review on FDI}

The economic literature on FDI determinants has concentrated mainly on analyzing why firms invest abroad. Some authors have studied the determinants of FDI at the macroeconomic level. They found that FDI is mainly determined by relative real wages, the relative exchange rate, economic integration, market size, cultural differences, infrastructure, credit access and economic stability. ${ }^{2}$

Another strand of the literature, where studies are scarcer and more relevant to the present study, analyses the determinants of FDI at industry or firm level. For example, for the firms in the manufacturing and services sectors in Sweden, Karpaty and Poldahl (2006) found that the factors associated with firms' ownership

2 In this group there are studies for groups of countries (i.e. Blonigen and Piger, 2011; Walsh and Yu, 2010; Demirhan and Masca, 2008; Bénassy-Quéré, Couper and Mayer, 2007; Albuquerque, Loayza and Serven, 2005; Liu, Song, Wei and Romilly, 1997), for regions (i.e. Ramirez, 2010 for Latin America; Sahoo, 2006 for Asia and Abor, 2010; Oladipo, 2010; Abor, Adjasi and Hayford, 2008; Ajayi, 2006; Asiedu, 2002 for Africa) and for individual countries (i.e. Grosse and Trevino, 1996 for the USA; Garcia-Herrero, Iizaka and Siu, 2005 and Wang and Swain, 1995, 1997 for China; Kimino, Saal and Driffield, 2007 for Japan; Love and LageHidalgo, 2000 for México; Ramírez, 2006 for Chile; Aqeel and Nishat, 2004 for Pakistan and Aw and Tang 2009 for Malaysia). 
and variables such as human capital, capital intensity and the intensity in the use of energy positively affect a firm's decision to invest in such sectors. Also, for the case of the food processing industry in the United Kingdom, Giulietti, Mccorriston and Osborne (2004) showed that the property of the firm and the market structure are important variables foreign companies considered when deciding to invest in this sector.

Buch, Kleinert, Lipponer and Toubal (2005) found that German multinationals companies mainly moved overseas to gain better access to international markets. Moreover Todo (2009) found evidence that the cost of entry into foreign markets plays an important role in the decision to invest abroad by Japanese firms.

Bellak, Leibrecht and Stehrer (2008) analyzed public policies to attract FDI, using a sample of countries, at the manufacturing industry level. The results showed that expenditure on research and development, unit labor costs, worker's ability, institutional environment and tax policy contribute to closing the gap between estimated FDI and its potential.

Alfaro and Charlton (2009) used a detailed database to characterize global patterns of multinational activity; they found that GDP is one of the main determinants of vertical FDI. On the contrary, bilateral distance, as a proxy for costs, and the increase in the level of skills in the subsidiary country have a negative effect on the multinational activity.

Finally, other studies have used surveys to ask entrepreneurs what reasons influence their decision to invest abroad. Hogenbirk (2002) conducted a survey among eighty six foreign electronics firms in the Netherlands. The survey asked the companies the reason why they set up business in the country. According to the results, factors associated with the ownership of the firms, location, and the benefits of internationalization affect the decision to locate in the Netherlands. Moreover, Ali and Guo (2005) analyzed the response of twenty two foreign firms operating in China on what they perceive as the most important factors for investing in that country. The survey results show market size is the main motivation for American firms, while low labor costs are the key determinant for Asian companies.

In summary, it's difficult to identify the most important factors affecting a firm's decision to invest abroad given that there is a wide range of methodologies and databases that include different samples of countries and time periods. However, from the literature review it is possible to establish that from a macroeconomic perspective market size, economic growth, the exchange rate, the tax structure, trade agreements, financial costs and macroeconomic stability are the most relevant factors. Moreover, from a microeconomic point of view 
the ownership structure of the firm, product differentiation, economies of scale and the firm's size are the most important aspects.

In Colombia, the determinants of FDI at the firm level have not been studied in depth. ${ }^{3}$ The literature has focused on FDI regulations (Steiner and Giedion, 1995; Corral and Anzola, 1998), the role of taxes to attract FDI (Echavarria and Zodrow, 2005) and the government policies to attract FDI (Kalin, 2009; De Lombaerde and Garay, 2009).

Another subject examined is the relationship between foreign investment, manufacturing exports and innovation (Fatat, 1998). In turn, Echavarria and Esguerra (1990) and Kalin (2009) examined the impact the presence of foreign companies in the country has on employment, wages, production and exports. Other authors have studied the relationship between FDI, productivity, externalities and technology diffusion in the manufacturing sector (i.e. Atallah, 2006; Kugler, 2006; De Lombaerde and Pedraza, 2004; Pedraza, 2003; Kugler, 1998 and Steiner and Giedion, 1995).

Finally, among the few studies that have used firm level data, Rowland (2006) compared foreign and domestic firms in terms of sales, the evolution in earnings, leverage, exports, imports and foreign debt. In addition, Pedraza (2003) explored how FDI flows directed to the Colombian industrial sector affected the productive performance of recipient firms and compared the productive performance of firms with foreign investment to the productivity achieved by local firms.

\section{Characterization of Firms Receiving FDI}

We analyze whether firms receiving FDI differ from those that do not receive this type of investment. ${ }^{4}$ To perform this analysis, we use a database consisting of 5,364 firms, mainly in the manufacturing sector $(28 \%)$, trade $(26 \%)$ and financial services $(19 \%)$, during the $2000-2010$ period. ${ }^{5} 30 \%$ of the firms in the

3 Garavito et al. (2012) present a detailed literature review.

4 See Appendix A for a description of the assembling process and the sources of the dataset.

5 The group of firms included in the study refers to a target population, i.e. all companies under supervision and monitoring of the Superintendencia de Sociedades, Superintendencia Financiera and Superintendencia de Servicios Públicos Domiciliarios. After the selection process described in Appendix A, 5,364 firms were obtained. This group includes all those firms with consistent and complete information for the period 2000-2010. In addition, it comprises large companies, ensuring the economic reliability of the results within the context of this study. 
entire sample have FDI. It is important to point out that $96 \%$ of the firms in the petroleum sector and $41 \%$ in mining receive FDI (table 1 ). The development of petroleum and mining projects in particular requires the involvement of foreign firms that can afford the high capital investment, technology and risks associated with this type of business.

Table 1. Sectoral Distribution of Firms, 2000-2010

\begin{tabular}{|c|c|c|c|c|c|c|}
\hline \multirow[b]{2}{*}{ Sector } & \multirow{2}{*}{$\begin{array}{l}\text { Number } \\
\text { of firms }\end{array}$} & \multirow{2}{*}{$\begin{array}{l}\text { Percentage } \\
\text { of firms }\end{array}$} & \multicolumn{2}{|c|}{ Firms without FDI } & \multicolumn{2}{|c|}{ Firms with FDI } \\
\hline & & & $\begin{array}{l}\text { Number } \\
\text { of firms }\end{array}$ & $\begin{array}{l}\text { Percentage } \\
\text { of firms }\end{array}$ & $\begin{array}{l}\text { Number } \\
\text { of firms }\end{array}$ & $\begin{array}{l}\text { Percentage } \\
\text { of firms }\end{array}$ \\
\hline $\begin{array}{l}\text { Agriculture, forestry and } \\
\text { fishing }\end{array}$ & 543 & 10,12 & 409 & 75,32 & 134 & 24,68 \\
\hline Mining & 39 & 0,73 & 23 & 58,97 & 16 & 41,03 \\
\hline Manufacturing & 1516 & 28,26 & 999 & 65,90 & 517 & 34,10 \\
\hline Electricity, gas and water & 30 & 0,56 & 16 & 53,33 & 14 & 46,67 \\
\hline Construction & 478 & 8,91 & 401 & 83,89 & 77 & 16,11 \\
\hline Trade & 1396 & 26,03 & 1030 & 73,78 & 366 & 26,22 \\
\hline $\begin{array}{l}\text { Transport, storage and } \\
\text { communication }\end{array}$ & 153 & 2,85 & 92 & 60,13 & 61 & 39,87 \\
\hline Financial services & 1024 & 19,09 & 697 & 68,07 & 327 & 31,93 \\
\hline Other services & 115 & 2,14 & 72 & 62,61 & 43 & 37,39 \\
\hline Petroleum & 70 & 1,30 & 3 & 4,29 & 67 & 95,71 \\
\hline Total & 5364 & 100,00 & 3742 & 69,76 & 1622 & 30,24 \\
\hline
\end{tabular}

Source: Superintendencia de Sociedades, Superintendencia Financiera, Superintendencia de Servicios Públicos Domiciliarios, Banco de la República; Own calculations.

In the electricity, gas and water sector, $47 \%$ of the firms received FDI. Since the beginning of the nineties, with the change in the international investment regime, foreign investors have been allowed to participate in most economic sectors, including the provision of public utilities. This, combined with the high amounts of investment required to develop infrastructure projects and the monopoly the investor can exploit in this sector, encouraged the arrival of foreign capital to this branch of economic activity.

In contrast, the sectors with the lowest percentage of firms with FDI are construction (16\%), agriculture (25\%) and trade (26\%) (table 1). Although foreign participation is, in general, relatively low for firms in those sectors, it is important to mention that FDI is significant for some subsectors within these activities (i.e. production and export of bananas and wholesale trade). 
In terms of the size of the firms with FDI, 77\% were classified as large, $14 \%$ as medium and 9\% as small. ${ }^{6}$ Furthermore, $73 \%$ of the firms with FDI are registered in Bogotá, 9\% in Medellin, 7\% in Cali, $4 \%$ in Barranquilla and $7 \%$ in the rest of the country. ${ }^{7}$ It is important to mention that $78 \%$ of the firms receiving FDI conducted some foreign trade activity. Moreover, in Colombia, an important amount of FDI is in the form of acquisitions of existing companies. Investors generally prefer to acquire large and well-established firms that allow them to participate in a relevant market share and well-established trade channels.

As seen in table 2, over $60 \%$ of the firms receiving FDI have had more than $90 \%$ a foreign equity, which confirms that foreign investors prefer to have total control of the company at the time of acquisition or merger. ${ }^{8}$ It should be noted that $3,1 \%$ of the firms receiving FDI issue securities, while only $1,1 \%$ of those that are not receiving this type of investment are.

Table 2. Foreign Capital: Percentage of firms by rank

\begin{tabular}{ccccccccccc}
\hline \multirow{2}{*}{ Year } & $10 \%-$ & $20 \%-$ & $30 \%-$ & $40 \%-$ & $50 \%-$ & $60 \%-$ & $70 \%-$ & $80 \%-$ & $90 \%-$ & \\
& $19,99 \%$ & $29,99 \%$ & $39,99 \%$ & $49,99 \%$ & $59,99 \%$ & $69,99 \%$ & $79,99 \%$ & $89,99 \%$ & $100 \%$ & Total \\
\hline 2000 & 5,5 & 3,8 & 3,6 & 6,1 & 6,1 & 3,1 & 3,6 & 5,9 & 62,3 & 100,0 \\
2001 & 4,7 & 4,2 & 4,3 & 6,0 & 5,6 & 3,8 & 3,8 & 5,5 & 62,2 & 100,0 \\
2002 & 4,4 & 3,8 & 4,5 & 5,6 & 5,7 & 3,7 & 3,8 & 5,5 & 63,1 & 100,0 \\
2003 & 4,9 & 3,5 & 4,1 & 5,5 & 6,2 & 3,4 & 3,5 & 4,8 & 64,0 & 100,0 \\
2004 & 5,0 & 3,5 & 4,3 & 5,3 & 6,0 & 3,4 & 4,1 & 4,6 & 63,9 & 100,0 \\
2005 & 5,2 & 3,6 & 3,8 & 5,8 & 6,0 & 3,0 & 3,9 & 4,7 & 63,8 & 100,0 \\
2006 & 5,1 & 4,0 & 3,6 & 5,6 & 6,1 & 3,2 & 3,9 & 4,5 & 64,0 & 100,0 \\
2007 & 5,1 & 4,6 & 4,4 & 5,4 & 5,8 & 3,1 & 4,2 & 4,9 & 62,5 & 100,0 \\
2008 & 5,5 & 4,1 & 4,1 & 5,7 & 5,9 & 3,2 & 4,1 & 5,2 & 62,1 & 100,0 \\
2009 & 5,2 & 3,7 & 3,8 & 5,8 & 6,2 & 3,5 & 4,4 & 4,7 & 62,8 & 100,0 \\
2010 & 5,0 & 3,7 & 3,8 & 5,8 & 6,1 & 3,5 & 4,7 & 5,1 & 62,4 & 100,0 \\
Average & 5,1 & 3,9 & 4,0 & 5,7 & 6,0 & 3,4 & 4,0 & 5,0 & 63,0 & 100,0 \\
\hline
\end{tabular}

Source: Superintendencia de Sociedades, Superintendencia Financiera, firms' web pages; Own calculations.

6 Calculated from firm's total assets based on criteria established by the Law 905 of 2004. A small firm is defined as having total assets between five hundred and one (501) and five thousand $(5,000)$ legal minimum monthly wages. A medium firm is one that has total assets between five thousand one $(5,001)$ and thirty thousand $(30,000)$ legal monthly minimum wages, and a large firm has assets greater than 30,001 legal minimum wages.

7 It is important to point out that if a firm is registered, for example in Bogotá, it does not necessarily imply that its operation is carried out in the same city. to $10 \%$.

8 It is considered that a firm receives FDI if its foreign equity is greater than or equal 
Additionally, over $30 \%$ of the firms from the sample are headquartered in the United States, 7\% in Spain, 6\% in Germany, 6\% in France and 5\% in the United Kingdom. It is important to mention that a significant share of companies are headquartered at offshore financial centers (15\%), because international investors seek such countries to manage their foreign investments as a way to reduce certain transaction costs. Among these countries are Panama $(8 \%)$, Cayman Islands (2\%), Bermuda (1,2\%) and the British Virgin Islands (1,2\%).

Regarding capital intensity, measured as the value of fixed assets divided by the total working population, firms receiving FDI are more physical capital intensive than other firms (table 3). This is because some of the main sectors that receive FDI (petroleum, mining and manufacturing) are capital intensive.

Table 3. Firms' Average Capital Intensity* (USD)

\begin{tabular}{cccc}
\hline Year & Firms without FDI & Firms with FDI & Mean difference tests $p$ - value \\
\hline 2000 & 39413 & 101187 & 0,000 \\
2001 & 34808 & 93673 & 0,000 \\
2002 & 29963 & 81626 & 0,000 \\
2003 & 25938 & 71887 & 0,000 \\
2004 & 30622 & 75603 & 0,000 \\
2005 & 32669 & 86413 & 0,000 \\
2006 & 32733 & 80545 & 0,000 \\
2007 & 36594 & 90503 & 0,000 \\
2008 & 39345 & 90888 & 0,000 \\
2009 & 36262 & 88216 & 0,000 \\
2010 & 41749 & 94527 & 0,000 \\
\hline
\end{tabular}

* Capital intensity = Property, plant and equipment (net) / total employees. The numerator was deflated by Colombian CPI, base year 2005, and converted to USD.

Source: Superintendencia de Sociedades, Superintendencia Financiera, Superintendencia de Servicios Públicos Domiciliarios, Banco de la República; Own calculations.

\section{Determinants of FDI in Colombia: An Econometric Estimation}

In the economic literature, there is a wide variety of theoretical models to explain the determinants of FDI and the location decision of multinational firms. According to Faeth (2009), these models generally are complementary and explain different aspects of FDI. Therefore, FDI should not be explained by a single model, but through a combination of them; see also Blanchard, Gaigné and Mathieu (2008). 
Faeth (2009) carries out a comprehensive review of the theoretical models and the FDI determinants deriving from them. ${ }^{9}$ To this end, the author classifies the models into nine groups. The first includes those dating back to the 1960s. In these models, market size and growth, political stability and factor costs are the main determinants of FDI. The second group considers models derived from the neoclassical theory, which is based on the international trade theory, particularly the Heckscher-Ohlin model. The third group of models, developed in the seventies, assumes imperfect markets; in these models monopolistic advantage, product differentiation, business management experience, economies of scale and patents are the main determinants of FDI. In the fourth group, the effect of aggregate variables on FDI, such as market size and trade barriers, is incorporated into the models.

However, the model of perhaps greater importance in literature is in the fifth group. It is known as Dunning's eclectic paradigm of international production and combines the theory of international trade and the theory of internalization. ${ }^{10}$ In this model, FDI is explained by three types of advantages: ownership specific advantages of the company (Ownership), location advantages of FDI host countries (Location) and internalization advantages of the firm's production process (Internalization). This model is known in literature as the OLI paradigm. As Faeth (2009) summarizes it, the advantages of business ownership include patents, know-how, management skills and reputation. The location is related to market access, favorable tax treatment and lower costs for production and transportation, while internalization is associated with benefits a company derives by replacing external markets with FDI.

The sixth group of models combines the advantages of ownership and location with technology and country characteristics. Another relevant model is the Knowledge-Capital model developed by Markusen, Venables, Konan and Zhang (1996). It combines both horizontal and vertical FDI determinants in a model that allows firms the option to build multiple plants and geographically separate headquarters and production; see also Markusen and Maskus (2002).

The eighth group is composed of models that assume firms are risk averse. Therefore, market and macroeconomic risks factors, such as exchange rate and interest rate volatility are considered as determinants of FDI. Finally, the last group includes theoretical models and policy variables such as tax and financial incentives, as well as subsidies.

\footnotetext{
9 For further details see the references mentioned in Faeth (2009) and Garavito et al. (2012).

10 For more details, see Dunning $(1979,1988,1998,2000)$.
} 
Based on the aforementioned and considering that the empirical analysis of FDI determinants is eclectic in nature, we estimate in this paper a model for the probability that a firm receives FDI, where the dependent variable takes the value of 1 if the company received FDI and 0 if not, according to the following equation:

$$
\begin{aligned}
& F_{i, t}=\beta_{1} \text { Stockmarket }_{i}+\beta_{2} \text { Age }_{i}+\beta_{3} \text { Sector }_{i}+\beta_{4} \text { Size }_{i}+\beta_{5} \text { Trade_openness }_{i}+
\end{aligned}
$$

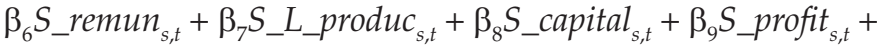

$$
\begin{aligned}
& \beta_{10} \text { VTTrade }_{t}+\beta_{11} C_{-} \text {intensity } \text { int }_{t}+\varepsilon_{i, t}
\end{aligned}
$$

Where Stockmarket ${ }_{i}$ is a dummy variable that takes the value of 1 if firm $i$ is listed on the National Stock Market and 0 otherwise; Trade_openness ${ }_{i}$ is a dummy variable that takes the value of 1 if the company exports and/or imports goods and services and 0 otherwise; ${ }^{11}$ Sector $_{i}$ and Size $_{i}$ are dummy variables that correspond to firm $i$ sector and size, respectively. ${ }^{12}$ The number of years the firm has been in business $\left(A g e_{i}\right)$ and a measure of the firm's capital intensity (C_intensity ${ }_{i, t}$ ) were also included. Moreover, we considered variables that change depending on the sector $s$ to which the firm $i$ belongs. These are indicators of profitability $\left(S \_\right.$profit $\left.t_{s, t}\right)$, capital intensity $\left(S \_c a p i t a l_{s, t}\right)$, labor productivity $\left(S \_L \_p r o d u c t, t_{s, t}\right)$ and labor remuneration $\left(S \_r e m u n_{s, t}\right)$. Finally, we included the volatility in the terms of trade $\left(\right.$ VTTrade $\left._{t}\right)$ in order to capture macroeconomic risk. ${ }^{13}$

Given the binary nature of the dependent variable, we estimated a discrete choice model; that is, a panel probit for the period 2000-2010, with information on 5,364 firms. We used the Population Averaged (PA) model, widely employed to estimate nonlinear models with panel data. The model assumes that the individual effects have been averaged, which facilitates estimating and interpreting the marginal effects (Cameron and Trivedi, 2005, 2009).

Table 4 shows the marginal effects from estimation of the PA model. The results indicate the probability that a firm has FDI decreases for companies operating in all economic sectors in relation to the petroleum sector, which was considered as the reference category. ${ }^{14}$ This can be explained by the fact that to

11 The variable Trade_openness is included to capture the firm's commercial openness. That is, if the firms that import and/or export are more likely to attract FDI than those that do not. Although an important share of firms operate in non-tradable sectors, they import goods to carry out their economic activity.

12 It is important to mention that initially we included a variable representing the place where a firm is registered. However, we decided against it since almost $75 \%$ of firms are register in Bogotá.

13 Appendix B presents the summary statistics of the variables.

${ }^{14}$ For the econometric estimation, the agriculture, forestry and fishing, mining, electricity, 
petroleum explotation requires, in most cases, foreign capital investment, given the high amounts of investment and risk involved in such activities. ${ }^{15}$

Table 4. Probability of a Firm Receiving FDI, 2000-2010

(Marginal Effects Obtained from a Population Averaged Model)

Estimation Method: Panel probit

Dependent variable: 1 if the firm receives FDI, 0 otherwise

\begin{tabular}{|c|c|c|c|c|c|c|}
\hline Variables & $\begin{array}{c}\text { Marginal } \\
\text { effects } \\
(d \mathrm{y} / d \mathrm{x})^{*}\end{array}$ & $\begin{array}{l}\text { Standard } \\
\text { error }\end{array}$ & $p$-value & \multicolumn{2}{|c|}{$\begin{array}{c}\text { Confidence } \\
\text { Interval (95\%) }\end{array}$} & \multirow{2}{*}{$\begin{array}{c}\bar{X} \\
0,0077\end{array}$} \\
\hline d_Listed on the stock market & 0,1982 & 0,0898 & 0,0270 & 0,0221 & 0,3742 & \\
\hline Firm's age & $-0,0009$ & 0,0006 & 0,1180 & $-0,0020$ & 0,0002 & 30,1053 \\
\hline d_Manufacturing & $-0,3563$ & 0,0329 & 0,0000 & $-0,4206$ & -0.2919 & 0,3198 \\
\hline d_Trade & $-0,3585$ & $-0,0302$ & 0,0000 & $-0,4177$ & $-0,2992$ & 0,2886 \\
\hline d_Transport & $-0,2181$ & 0,0275 & 0,0000 & $-0,2719$ & $-0,1643$ & 0,0303 \\
\hline d_Financial services & $-0,2105$ & 0,0320 & 0,0000 & $-0,2731$ & $-0,1478$ & 0,1202 \\
\hline d_Other sectors & $-0,3248$ & $-0,0270$ & 0,0000 & $-0,3778$ & $-0,2719$ & 0,2210 \\
\hline d_Trade_openness & 0,1865 & 0,0154 & 0,0000 & 0,1563 & 0,2167 & 0,7120 \\
\hline d_Small & $-0,1659$ & $-0,0164$ & 0,0000 & $-0,1980$ & $-0,1338$ & 0,1332 \\
\hline d_Medium & $-0,1850$ & $-0,0137$ & 0,0000 & $-0,2119$ & $-0,1582$ & 0,2508 \\
\hline Sectoral labor remuneration & 0,0026 & 0,0011 & 0,0200 & 0,0004 & 0,0049 & 0,3321 \\
\hline Sectoral labor productivity & 0,0000 & 0,0000 & 0,0020 & 0,0000 & 0,0000 & $2,3 \mathrm{E}+07$ \\
\hline Sectoral capital intensity & 0,0001 & 0,0000 & 0.0000 & 0,0000 & 0,0001 & 1,1909 \\
\hline Sectoral profitability & 0,0008 & 0,0007 & 0,2410 & $-0,0005$ & 0,0021 & 0,3232 \\
\hline Terms of trade volatility & $-0,0003$ & 0,0001 & 0,0000 & $-0,0004$ & $-0,0001$ & 0,0367 \\
\hline Firms' capital intensity & 0,0000 & 0,0000 & 0,0030 & 0,0000 & 0,0000 & $1,1 \mathrm{E}+05$ \\
\hline Number of observations & 50861 & & & & & \\
\hline \multirow[t]{2}{*}{ Wald Test } & \multicolumn{2}{|c|}{$\operatorname{chi} 2(14)=708,03$} & & & & \\
\hline & \multicolumn{2}{|c|}{ Prob > chi $2=0,0000$} & & & & \\
\hline
\end{tabular}

* dy/dx is for discrete change of dummy variable from 0 to 1 .

Source: own estimations.

gas and water, construction and social services sectors were grouped into a sector called "other sectors".

15 As an additional exercise, we attempted to estimate the model by sector. However, due to numerical problems in the optimization, estimation was not possible given the low variability of the dependent variable at this level. 
In terms of size, the probability also declines for small and medium sized firms in relation to large companies. Likewise, the probability of a firm having FDI increases if it is listed on the National Stock Market and if it conducts foreign trade activities. In this case, foreign investors are looking to invest in major companies as a way to gain quick access to representative market shares and to well-established business structures and marketing channels to obtain operating results in the short term. Moreover, the greater capital intensity, both at sectoral and firm level, and the greater sectoral labor remuneration the more likely it is for firms to have FDI. The results also show firms are risk averse, because the higher the volatility in the terms of trade, the less likelihood of a firm having FDI. ${ }^{16}$

We also performed an exercise considering the foreign share of firms' capital $\left(\right.$ Foreing $\left._{i, t}\right)$ as a dependent variable to capture the change in the firms' capital composition over time (equation 2). In this specification we use, besides the variables included in equation 1 , some additional regressors:

$$
\begin{aligned}
& \text { Foreing }_{i, t}=\beta_{1} \text { Stockmarket }_{i}+\beta_{2} \text { Age }_{i}+\beta_{3} \text { Sector }_{i}+\beta_{4} \text { Size }_{i}+\beta_{5} \text { Trade_openness }_{i}
\end{aligned}
$$

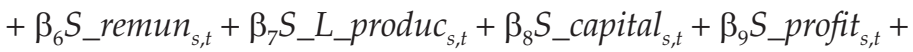

$$
\begin{aligned}
& \beta_{10} R \_ \text {diff }_{s, t}+\beta_{11} \text { VTTrade }_{t}+\beta_{12} \text { Tax }_{t}+\beta_{13} \text { Law }_{t}+\beta_{14} \text { C_intensity } \text { int }_{i, t}+\varepsilon_{i, t}
\end{aligned}
$$

Where $R \_$diff is is the interest rate differential as a proxy of implicit FDI profitability; $\operatorname{Tax}_{t}$ is the corporate income tax rate included to capture tax incentives, and $L_{a w}$ is a measure of the rule of law as a proxy for the quality of institutions.

The dependent variable takes values in the interval between 0 and 1 ; it is bound at both ends and presents excess zeros. To overcome these drawbacks, the usual practice is to transform the variable using the logistic transformation, so the modified series takes values in the real line, allowing us to use the standard regression analysis (Cribari-Neto and Zeileis, 2010). Additionally, due to the presence of extreme values, it was necessary to do the following transformation before performing the logistic transformation:

$$
(y(n-1)+0,5) / n
$$

16 In an additional estimation, we replaced volatility in terms of trade with real exchange rate volatility and found the likelihood of a company having FDI declines when this volatility increases; the result is consistent with the risk aversion of entrepreneurs. Firms' profitability indicators also were included as explanatory variables, but were not significant in the estimations. These results are not reported here to save space, but are available on request. 
Where $y$ and $n$ are the variable to be transformed and the number of observations, respectively.

Table 5 shows the results of the determinants of the foreign share of the firms' capital for the 2000-2010 period, using panel data with random effects. The estimated parameters only provide information about the sign and the significance of the variables, as these are interpreted in terms of the average of $\tilde{y}$ (transformed variable) rather than the mean of $y$. The results indicate the percentage of foreign ownership in firms belonging to the petroleum sector, large in size and engaged in foreign trade activities is higher than for other companies. Regarding the age of the firms, we found foreign interest in firms' capital is lower for older firms than for newer ones. Regarding the sectoral variables, the results show labor remuneration, capital intensity, labor productivity and profitability have a positive and significant effect on firms' foreign ownership. Moreover, volatility in terms of trade and the corporate income tax rate negatively affect foreign ownership interest. Finally, foreign ownership is favored by an improvement in the rule of law indicator, as well as by a higher implicit FDI profitability (interest rate differential).

Table 5. Estimation Results of the Foreign Share in the Firms' Capital Model: 2000-2010 (Random Effects)

\begin{tabular}{lrcc}
\hline Variables & Coefficients & Standard error & $p$-value \\
\hline d_Listed on the stock market & 0,1815 & 1,2085 & 0,8810 \\
Firms' age & $-0,0480$ & 0,0082 & 0,0000 \\
d_Manufacturing & $-9,1450$ & 0,7982 & 0,0000 \\
d_Trade & $-7,0723$ & 0,8457 & 0,0000 \\
d_Transport & $-6,0706$ & 1,0004 & 0,0000 \\
d_Financial services & $-5,9661$ & 0,8338 & 0,0000 \\
d_Other sectors & $-7,6293$ & 0,8417 & 0,0000 \\
d_Trade_openness & 3,7353 & 0,2719 & 0,0000 \\
d_Small & $-2,2488$ & 0,3231 & 0,0000 \\
d_Medium & $-2,5853$ & 0,2531 & 0,0000 \\
Sectoral labor remuneration & 0,0525 & 0,0092 & 0,0000 \\
Sectoral capital intensity & 0,0009 & 0,0003 & 0,0060 \\
Sectoral labor productivity & 0,0000 & 0,0000 & 0,0260 \\
Sectoral profitability & 0,0391 & 0,0060 & 0,0000 \\
Terms of trade volatility & $-2,3766$ & 1,1570 & 0,0400 \\
& & & Continue
\end{tabular}




\begin{tabular}{llll} 
Corporate income tax rate & $-2,1679$ & 0,6115 & 0,0000 \\
Rule of Law & 0,8803 & 0,0766 & 0,0000 \\
Firms' capital intensity & 0,0000 & 0,0000 & 0,0000 \\
Interest rate differential & 0,0220 & 0,0043 & 0,0000 \\
Constant & -2.1510 & 1,0655 & 0,0440 \\
Number of observations & 50861 & \\
Wald test & $\operatorname{chi}^{2}(19)=1714,98$ & \\
& \multicolumn{2}{c}{${\text { Prob }>\mathrm{chi}^{2}=0,0000}$}
\end{tabular}

Breusch and Pagan Test ( Lagrange multiplier for random effects)

$$
\begin{gathered}
\operatorname{chibar}^{2}(01)=2,1 \mathrm{e}+05 \\
\text { Prob }>\operatorname{chibar}^{2}=0,0000
\end{gathered}
$$

Source: Own estimations.

Then, we calculated the expected effect on the dependent variable of a change in some of the independent variables, keeping the other variables constant. The expected change in $y, \Delta y$, associated with a change in $x_{1}$ (explanatory variables), $\Delta x_{1}$, keeping $x_{2}, \ldots, x_{k}$ constant, is the difference between the value obtained from the regression before and after the change in $x_{1}$, maintaining the other variables constant (Stock and Watson, 2007, Chapter 8). These effects can be calculated at different points of the variables, the average being the most used. Table 6 presents some examples of the expected effect on the dependent variable of the change in some of the explanatory variables, which are not dichotomous, relative to the baseline scenario. ${ }^{17}$ In particular, we considered a $1 \%$ change in each of the independent variables, keeping the other constant.

Table 6. Expected Impact of Several Factors that Help to Explain the Foreign Share in the Firms' Capital: 2000-2010

(Percentage Change in the Dependent Variable)

\begin{tabular}{lcc}
\hline \multicolumn{1}{c}{ Variables } & Marginal effect & $\overline{\mathrm{X}}$ \\
\hline Sectoral labor remuneration & 1,7600 & 0,3321 \\
Sectoral capital intensity & 0,1100 & 1,1909 \\
Sectoral labor productivity & 0,1699 & $2,3 \mathrm{E}+07$ \\
& & Continue
\end{tabular}

17 To save space, the results for all dummy variables are not presented due to the large number of possible combinations and interactions, but are available on request. 


\begin{tabular}{lcc}
\hline \multicolumn{1}{c}{ Variables } & Marginal effect & $\overline{\mathrm{X}}$ \\
\hline Sectoral profitability & 1,2709 & 0,3232 \\
Terms of trade volatility & $-0,0871$ & 0,0367 \\
Corporate income tax rate & $-0,7625$ & 0,3531 \\
Rule of Law & 0,5738 & $-0,6500$ \\
Interest rate differential & 0,0774 & 3,5211 \\
Firms' capital intensity & 0,0383 & 113926 \\
\hline
\end{tabular}

${ }^{*} 1 \%$ change in independent variables.

Source: Own calculations.

The results show the $1 \%$ increase in labor remuneration would raise foreign participation by $1,8 \%$. Increasing sectoral capital intensity, labor productivity and profitability would raise the foreign share by $0,11 \%, 0,17 \%$ and $1,3 \%$, respectively. Similarly, improving the rule of law indicator, the interest rate differential and the firms' capital intensity by $1 \%$, the foreign share would increase by $0,6 \%$, $0,08 \%$ and $0,04 \%$, respectively. In contrast, an increase in the corporate income tax rate would lower the foreign share by $0,8 \%$, while an increase in terms of trade volatility would reduce it by $0,1 \%$.

It is important to note that the determinants of the foreign share in the firms' capital may differ, depending on the sector where the investment is made. In general, we find there are no significant differences at sectoral level. ${ }^{18}$ For example, an improvement in the rule of law indicator, the fact that the firm is engaged in foreign trade activities, and has a higher capital intensity encourage foreign participation in the firms' capital in most sectors. Moreover, a higher interest rate differential is important for firms in the agricultural sector, trade, manufacturing, and in social and personal services. In large companies, foreign participation is higher for firms belonging to the trade sector, manufacturing, transport, storage, and communications and financial services.

Regarding the firms' age, the results suggest older firms would have a minor foreign involvement in the mining and quarrying, transport, storage and communications, financial services, and trade sectors while this share increases with the age of the firm in the manufacturing sector. With respect to corporate income taxes, they negatively affect foreign participation in the trade, manufacturing and financial services sectors.

Table 7 shows some examples of the expected effect a change in some of the explanatory variables, which are not dichotomous in relation to the baseline

18 These results are not reported here to save space, but are available on request. 
scenario, would have on the foreign share of the capital of companies, by economic sector. A $1 \%$ change in each of the independent variables, keeping the other variables constant, is considered. The results show an increase in the corporate income tax rate would decrease foreign participation by $0,9 \%$ in manufacturing, $1 \%$ in trade and 1,3\% in financial services. By improving the indicator of the rule of law, the marginal effect is greater in the mining and quarrying $(1,4 \%)$ than in the other sectors. In this particular case, the places where firms operate are close to armed conflict zones; therefore an improvement in the rule of law has a positive effect on firms' conditions, making them more attractive to foreign investors.

Table 7. Expected Impact of Several Factors that Help Explain the Foreign Share in the Firms' Capital, by Sector: 2000-2010

(Percentage Change in the Dependent Variable)

\begin{tabular}{|c|c|c|c|c|c|c|c|c|}
\hline \multirow[t]{2}{*}{ Sector } & \multicolumn{2}{|c|}{ Income tax } & \multicolumn{2}{|c|}{ Rule of law } & \multicolumn{2}{|c|}{$\begin{array}{l}\text { Interest rate } \\
\text { differentials }\end{array}$} & \multicolumn{2}{|c|}{$\begin{array}{l}\text { Firm's capital } \\
\text { intensity }\end{array}$} \\
\hline & $\begin{array}{l}\text { Mar- } \\
\text { ginal } \\
\text { effect }\end{array}$ & $\bar{x}$ & $\begin{array}{l}\text { Mar- } \\
\text { ginal } \\
\text { effect }\end{array}$ & $\bar{x}$ & $\begin{array}{l}\text { Mar- } \\
\text { ginal } \\
\text { effect }\end{array}$ & $\bar{x}$ & $\begin{array}{l}\text { Mar- } \\
\text { ginal } \\
\text { effect }\end{array}$ & $\bar{x}$ \\
\hline $\begin{array}{l}\text { Agriculture, forestry } \\
\text { and fishing }\end{array}$ & & & 0,560 & $-0,6472$ & 0,158 & 3,5424 & & \\
\hline Mining & & & 1,432 & $-0,6525$ & & & & \\
\hline Manufacturing & $-0,880$ & 0,3531 & 0,674 & $-0,6498$ & 0,106 & 3,5170 & & \\
\hline Construction & & & & & & & 0,071 & 77746 \\
\hline Trade & $-1,029$ & 0,3531 & 0,413 & $-0,6505$ & 0,067 & 3,5122 & 0,021 & 43079 \\
\hline $\begin{array}{l}\text { Transport, storage and } \\
\text { communication }\end{array}$ & & & 0,895 & $-0,6520$ & & & 0,219 & 567066 \\
\hline Financial services & $-1,268$ & 0,3530 & 0,827 & $-0,6484$ & & & 0,161 & 245799 \\
\hline Other services & & & & & 0,247 & 3,5750 & 0,279 & 52527 \\
\hline
\end{tabular}

${ }^{*} 1 \%$ change in independent variables.

Source: Own calculations.

In addition, an increase in the interest rate differential would raise foreign participation by $0,2 \%$ in agriculture, forestry and fishing, $0,1 \%$ in manufacturing and trade sector and by $0,3 \%$ in social, personal and community services. Finally, the highest marginal effect on foreign participation from an increase in the firms' capital intensity is found in social, personal and community services $(0,3 \%)$. 


\section{Conclusions}

We put together a panel data containing information on firm's characteristics, macroeconomic variables and sectorial variables to investigate the determinants of FDI in Colombia at the firm level, during a period characterized by increasing capital inflows.

Our empirical analysis involves two econometric exercises: in the first one, we estimate a model for the determinants of the probability that a firm receives FDI, while in the second one we focus on the factors that could explain the foreign share in a firm's capital.

Overall, the results of both estimations are qualitatively similar. We find that the probability that a firm receives FDI reduces for firms in economic sectors other than petroleum, and for small- and medium-sized companies. In contrast, the probability of receiving FDI increases for firms involved in foreign trade activities, those in sectors with higher capital intensity, and in firms listed on the stock market. We also found firms are risk averse, because the higher the volatility of terms of trade the less likely it is that a company receives FDI.

Regarding the results of the determinants of the foreign share of company capital, it is worth pointing out that sectorial variables, such as labor remuneration, capital intensity, labor productivity and profitability, have a positive and statistically significant effect on this share. Also, the corporate income tax rate negatively affects the foreign share, while an improvement in the indicator of the rule of law encourages it. In summary, our results suggest that in the interest of obtaining operating results in the short term, foreign investors' decisions appear to be biased in favor of major companies with an already significant access to important market shares, well-established business structures and marketing channels. An important institutional aspect is related to the fact that firms that issue securities look appealing to market participants, because this financing method is employed by firms with a transparent code of governance, and supervised by a financial regulator. Lastly, it would be interesting to compare whether the factors that appear to drive foreign investors' decisions on Colombian firms are similar to those that are considered in other countries. This, however, is a topic for future research.

\section{References}

Abor, J. (2010). Foreign Direct Investment and Firm Productivity: Evidence from Firm-Level Data. Global Business and Economics Review, 12(4), 267-285. 
Abor, J., Adjasi, C. \& Hayford, M. MC. (2008). How Does Foreign Direct Investment Affect the Export Decisions of Firms in Ghana? African Development Review 20(3), 446-465.

Ajayi, S. I. (2006). Foreign Direct Investment in Sub-Saharan Africa: Origins, Targets, Impact and Potential. Nairobi: African Economic Research Consortium.

Albuquerque, R., Loayza, N. \& Servén, L. (2005). World Market Integration through the Lens of Foreign Direct Investors. Journal of International Economics, 66(2), 267-295.

Alfaro, L. \& Charlton, A. (2009). Intra-Industry Foreign Direct Investment. American Economic Review, 99(5), 2096-2119.

Ali, S. \& Guo, W. (2005). Determinants of FDI in China. Journal of Global Business and Technology, 1(2), 21-33.

Aqeel, A. \& Nishat, M. (2004). The Determinants of Foreign Direct Investment in Pakistan. The Pakistan Development Review, 43(4) Part II: 651-664.

Asiedu, E. (2002). On the Determinants of Foreign Direct Investment to Developing Countries: Is Africa Different? World Development, 30(1), 107-119.

Atallah, S. (2006). Revaluando la transmisión de spillovers de la IED: un estudio de productividad para Colombia. Revista Desarrollo y Sociedad, 57, 163-213.

Aw, Y. T. \& Tang, T. C. (2009). The Determinants of Inward Foreign Direct Investment: The Case of Malaysia. Monash Economics Working Papers, 22-09.

Bellak. C., Leibrecht, M. \& Stehrer, R. (2008). The Role of Public Policy in Closing the FDI Gaps: An Empirical Analysis. The Vienna Institute for International Economic Studies, Working Paper 48.

Bénassy-Quéré, A., Coupet, M. \& Mayer, T. (2007). Institutional Determinants of Foreign Direct Investment. The World Economy, 30(5), 764-782.

Blanchard, P., Gaigné, C. \& Mathieu, C. (2008). Foreign Direct Investment: Lessons from Panel Data. In László Mátyás and Patrick Sevestre (ed.). The Econometrics of Panel Data. Advanced Studies in Theoretical and Applied Econometrics (3 ${ }^{\text {rd }}$ ed.), (pp. 663-696). Berling: Springer.

Blonigen, B. A. \& Piger, J. (2011). Determinants of Foreign Direct Investment. NBER Working Paper 16704. Retrieved from http: / / www.nber.org/papers / w16704

Buch, C., Kleinert, J., Lipponer, A. \& Toubal, F. (2005). Determinants and Effects of Foreign Direct Investment: Evidence from German Firm-Level Data. Economic Policy, 20, 52-110.

Cameron, A. C. \& Trivedi P. K. (2005). Microeconometrics Methods and Applications, New York: Cambridge University Press.

Cameron, A. C. \& Trivedi P. K. (2009). Microeconometrics using Stata. Texas: Stata Press, StataCorp LP. 
Corral, L. C. \& Anzola, M. (1998). Inversión extranjera directa en Colombia, 1990-1998. Revista de Planeación y Desarrollo, 29, 149-176.

Cribari-Neto, F. \& Zeileis, A. (2010). Beta Regression in R. Journal of Statistical Software, 34, 1-24.

Demirhan, E. \& Masca, M. (2008). Determinants of Foreign Direct Investment Flows to Developing Countries: A Cross-Sectional Analysis. Prague Economic Papers 4, 356-369.

De Lombaerde, P. \& Garay, L. J. (2009). FDI Policies in Times of Conflict: The Case of Colombia. UNU-CRIS Working Papers, No W-2009/23.

De Lombaerde, P. \& Pedraza, E. B.. (2004). FDI Productivity Spillovers in the Andean Region: Econometric Evidence from Colombian Firm-Level Panel Data. UNU-CRIS Occasional Papers, 0-2004/14.

Dunning, J. H. (1979). Explaining Changing Patterns of International Production: In Defence of Eclectic Theory. Oxford Bulletin of Economics and Statistics, 41(4), 269-296.

Dunning, J. H. (1988). The Eclectic Paradigm of International Production: A Restatement and Some Possible Extensions. Journal of International Business Studies, 19(1), 1-31.

Dunning, J. H. (1998). Location and the Multinational Enterprise: A Neglected Factor? Journal of International Business Studies, 29(1), 45-66.

Dunning, J. H. (2000). The Eclectic Paradigm as an Envelope for Economic and Business Theories of MNE Activity. International Business Review, 9(2), 163-190.

Echavarría, J. J. \& Esguerra, P. (1990). Empresas transnacionales y reestructuración industrial en Colombia. Revista de Planeación y Desarrollo, 22, 41-90.

Echavarría, J. J. \& Zodrow, G. R. (2005). Foreign Direct Investment and the Business Tax in Colombia. In Bird, R., Poterba, J. \& Slemrod, J. (Eds.) Fiscal Reform in Colombia: Problems and Prospects, (pp. 153-190). Cambridge: MIT Press.

Faeth, I. (2009). Determinants of Foreign Direct Investment - A Tale of Nine Theoretical Models. Journal of Economic Surveys 23(1), 165-196.

Fatat, Abdul. (1998). Inversión extranjera, exportaciones e innovación tecnológica en la industria colombiana, 1992-1997. Revista de Planeación y Desarrollo, 29, 117-147.

Fung, K. C., Garcia-Herrero, A., Iizaka, H. \& Siu, A. (2005). Hard or Soft? Institutional Reforms and Infrastructure Spending as Determinants of Foreign Direct Investment in China. The Japanese Economic Review, 56(4), 408-416.

Garavito, A., Iregui, A. M. \& Ramírez, M. T. (2012). Inversión extranjera directa en Colombia: evolución reciente y marco normativo. Borradores de Economía, 713. 
Giulietti, M., McCorriston, S. \& Osborne, P. (2004). Foreign Direct Investment in the UK: Evidence from a Disaggregated Panel of the UK Food Sector. Applied Economics, 36(7), 653-663.

Grosse, R. \& Trevino, L. (1996). Foreign Direct Investment in the United States: An Analysis by Country of Origin. Journal of International Business Studies, 27(1), 139-155.

Hogenbirk, A. E. (2002). Determinants of Inward Foreign Direct Investment: The Case of the Netherlands. (Doctoral dissertation, Universidad de Maastricht, Netherlands).

International Monetary Fund. (1993). Balance of Payments Manual. (V edition). Washington D.C.: International Monetary Fund.

Kalin, Y. (2009). FDI in Colombia: Policy and Economic Effects. Minor Field Studies 196. Retrieved from http://www.nek.lu.se/Publ/mfs/196.pdf.

Karpaty, P. \& Poldahl, A. (2006). The Determinants of FDI Flows Evidence from Swedish Manufacturing and Service Sector. The Swedish Network for European Studies in Economics and Business, Discussion paper 339. Retrieved from http:/ / www.snee.org/filer/papers/339.pdf.

Kimino, S., Saal, D. \& Driffield, N. (2007). Macro Determinants of FDI Inflows to Japan: An Analysis of Source Country Characteristics. The World Economy, 30(3), 446-469.

Kugler, Maurice. (1998). Dinámica de la productividad multisectorial: la inversión extranjera directa como canal de difusión tecnológica. Revista Desarrollo y Sociedad, 42, 43-79.

Kugler, Maurice. (2006). Spillovers from Foreign Direct Investment: Within or Between Industries. Journal of Development Economics, 80(2), 444-477.

Liu, X., Song, H., Wei, Y. \& Romilly, P. (1997). Country Characteristics and Foreign Direct Investment in China: A Panel Data Analysis. Review of World Economics, 133(2), 313-329.

Love, J. \& Lage-Hidalgo, F. (2000). Analysing the Determinants of US Direct Investment in Mexico. Applied Economics, 32(10), 1259-1267.

Markusen, J., Venables, A., Konan, D. \& Zhang, K. (1996). A Unified Treatment of Horizontal Direct Investment, Vertical Direct Investment, and the Pattern of Trade in Goods and Services. NBER Working Paper 5696.

Markusen, J. \& Maskus, K. (2002). Discriminating among Alternative Theories of the Multinational Enterprise. Review of International Economics, 10(4), 394-707.

Oladipo, O. S. (2010). Foreign Direct Investment (FDI): Determinants and Growth Effects in a Small Open Economy. The International Journal of Business and Finance Research, 4(4), 75-88. 
Pedraza, E. (2003). Desempeño económico por tipo de firma: Empresas nacionales vs. grandes y pequeñas receptoras de inversión extranjera. Archivos de Economía, 225, Bogotá: Departamento Nacional de Planeación.

Ramírez, M. (2006). Economic and Institutional Determinants of Foreign Direct Investment in Chile: A Time-Series Analysis, 1960-2001. Contemporary Economic Policy 24(3), 459-471.

Ramírez, M. (2010). Economic and Institutional Determinants of FDI Flows to Latin America: A Panel Study. Working Papers, 1003, Trinity College, Department of Economics. Retrieved from http:/ /internet2.trincoll.edu/ repec/WorkingPapers2010/wp10-03.pdf.

Rowland, P. (2006). Foreign and Domestic Firms in Colombia: How Do They Differ? Borradores de Economía, 375.

Sahoo, P. (2006). Foreign Direct Investment in South Asia: Policy, Trends, Impact and Determinants. Asian Development Bank Institute Discussion Paper, 56. Retrieved from http://www.adbi.org/files/dp56_fdi_in_south_asia.pdf.

Steiner, R. \& Giedión, U. (1995). Characteristics, Determinants and Effects of Foreign Direct Investment in Colombia. In Manuel R. Agosín. (Ed.) Foreign Direct Investment in Latin America. Washington D. C.: Inter-American Development Bank and Universidad de Chile.

Stock, J. H. \& Watson, M. W. (2007). Introduction to Econometrics (2 ${ }^{\text {nd }}$ Ed). New York: Pearson Education.

Todo, Y. (2009). Quantitative Evaluation of Determinants of Export and FDI: Firm-level Evidence from Japan. Research Institute of Economy, Trade and Industry (RIETI) Discussion papers, 09019. Retrieved from http:/ / www. rieti.go.jp/jp/publications/dp/09e019.pdf.

Walsh, J. \& Yu, J. (2010). Determinants of Foreign Direct Investment: A Sectoral and Institutional Approach. IMF Working Paper 10/187. International Monetary Fund. Retrieved from http://econpapers.repec.org/ RePEc:imf:imfwpa:10/187.

Wang, Z. \& Swain, N. (1995). The Determinants of Foreign Direct Investment in Transforming Economies: Empirical Evidence from Hungary and China. Review of World Economics, 131(2), 359-382.

Wang, Z. \& Swain, N. (1997). Determinants of Inflow of Foreign Direct Investment in Hungary and China: Time-Series Approach. Journal of International Development, 9(5), 695-726. 


\section{Appendix A}

\section{Data sources}

In this appendix we present the data sources we used in our analysis. To assemble this firm-level database we combined financial statements from Superintendencia de Sociedades, Superintendencia Financiera and Superintendencia de Servicios Públicos Domiciliarios together with FDI records and the foreign trade database from the Banco de la República.

Regarding the Superintendencia de Sociedades we used the "Sistema de Información y Riesgo Empresarial" (SIREM) which contains financial statements and cash flow data for firms that are subject to inspection and supervision from this superintendence as well as for some firms under the supervision of Superintendencia Financiera. ${ }^{19}$ These data are available for the period 1995-2010. We also had access to firms financial annexes 12A (percentage of foreign equity) and 15 (permanent employees), which are available from 2000 to 2010.

In turn, from the Superintendencia Financiera we obtained financial statements for credit institutions (banks, financial corporations and commercial finance companies), insurance companies and bonded warehouses. Furthermore, from "Sistema Integral de Información del Mercado de Valores" (SIMEV) we found information about issuers of securities.

The above information was combined with FDI records and the foreign trade database from Banco de la República. Investment records are available for the period 2000-2010, whereas the foreign trade database that contains information on firms' exports and imports is available from 1995 to 2010. After combining these databases we found out that some public utilities did not have financial information. Hence, we resorted to the "Sistema Único de Información" (SUI) from the Superintendencia de Servicios Públicos Domiciliarios. Given the availability of the FDI records, the period 2000-2010 was chosen.

Then, we put all the sources of information together and obtained 215,015 observations, corresponding to 29,200 companies. Initially, from the resulting dataset we excluded micro-enterprises, liquidated firms and entities from the national, departmental and municipal governments.

Furthermore, a number of inconsistencies and gaps in the information that prevented assembling a consistent and reliable firm-level data set were found. In particular, we found inconsistent financial data: for example, liabilities that exceeded the value of assets, negative operating income, fixed assets larger than

${ }^{19}$ See http:/ / sirem.supersociedades.gov.co/SIREM. 
total assets, negative values of assets and/or liabilities, current assets larger than total assets, current liabilities larger than total liabilities, very low value of assets, unit problems (i.e. some years the information was reported in thousands, and others in millions) and outliers, among others.

Taking the above into consideration, as far as possible, missing information was completed using other sources and firms presenting inconsistent data were eliminated. As a result, a dataset of 148,973 observations was obtained for 20,868 firms. However, the number of firms varied greatly from year to year which could affect our econometric estimates. For example, in the year 2000 we had 7,168 firms while in 2010 our database consisted of 18,466 firms. Hence, it was decided to use a balanced panel including only firms with consecutive information for the period 2000 to 2010.

The final database consists of 59,004 observations for 5,364 firms, which were grouped into 10 economic sectors, according to the International Standard Industrial Classification (ISIC), revision 3. The sectors are: i) Agriculture, hunting, forestry and fishing; ii) trade, restaurants and hotels; iii) construction; iv) mining and quarrying; v) electricity, gas and water; vi) manufacturing; vii) financial institutions; viii) transport, storage and communications; ix) oil and $\mathrm{x}$ ) community, social and personal services.

Finally, sectoral variables, which are common to firms operating in the same sector were included in our estimations; the source of this information is DANE. These variables are: compensation of employees, value added, employed population by industry and gross operating surplus. Macroeconomic variables were also considered (i.e., terms of trade volatility, the tax rate on income and the price of oil). The rule of law as an institutional variable was also included. The sources of these variables are Banco de la República, DIAN, Datastream and the World Bank, respectively.

Table A.1. Variables: Sources and Definitions

\begin{tabular}{|c|c|c|}
\hline Variable & Description & Source \\
\hline Foreign share in firms' capital & Between 0 and $100 \%$ & $\begin{array}{l}\text { Supersociedades, Superfinan- } \\
\text { ciera, and firms' web pages }\end{array}$ \\
\hline Firms' FDI income & & Banco de la República \\
\hline $\begin{array}{l}\text { Date of firms' listing on the } \\
\text { stock market }\end{array}$ & & Colombian Stock Market \\
\hline Date of firm's establishment & & $\begin{array}{l}\text { Supersociedades and firms' } \\
\text { web pages }\end{array}$ \\
\hline Number of firms' employees & & $\begin{array}{l}\text { Supersociedades, Superfinan- } \\
\text { ciera, and firms' web pages }\end{array}$ \\
\hline
\end{tabular}




\begin{tabular}{|c|c|c|}
\hline Variable & Description & Source \\
\hline Economic sector & & $\begin{array}{l}\text { Supersociedades, } \\
\text { Superfinanciera, } \\
\text { and firms' web pages }\end{array}$ \\
\hline Firms' registration place & & $\begin{array}{l}\text { Supersociedades, } \\
\text { Superfinanciera, } \\
\text { and firms' web pages }\end{array}$ \\
\hline Firms' size & Law 905 of 2004 & $\begin{array}{l}\text { Supersociedades, Superfinan- } \\
\text { ciera, and firms' web pages }\end{array}$ \\
\hline $\begin{array}{l}\text { Residence country of firms' } \\
\text { headquarters }\end{array}$ & & $\begin{array}{l}\text { Supersociedades, Superfinan- } \\
\text { ciera, and firms' web pages }\end{array}$ \\
\hline Firms' capital intensity & $\begin{array}{l}\text { Property, plant and equip- } \\
\text { ment (net) / total employees. } \\
\text { The numerator was deflated } \\
\text { by Colombian CPI, base year } \\
2005 \text {, and converted to USD }\end{array}$ & Firms' balance sheets \\
\hline Sectoral labor remuneration & $\begin{array}{l}\text { Sectoral labor remuneration } \\
\text { and value added ratio }\end{array}$ & DANE \\
\hline Sectoral profitability & $\begin{array}{l}\text { Gross operating surplus / } \\
\text { value added }\end{array}$ & DANE \\
\hline Sectoral labor productivity & $\begin{array}{l}\text { Real value added (Base year } \\
2005 \text { ) / employed population. } \\
\text { The numerator was converted } \\
\text { to USD }\end{array}$ & DANE \\
\hline Sectoral capital intensity & $\begin{array}{l}\text { Gross operating surplus / re- } \\
\text { muneration to employees }\end{array}$ & DANE \\
\hline $\begin{array}{l}\text { Volatility of real exchange rate } \\
\text { index }\end{array}$ & $\begin{array}{l}\text { Standard deviation of real } \\
\text { exchange rate index }\end{array}$ & $\begin{array}{l}\text { Banco de la República and } \\
\text { own calculations }\end{array}$ \\
\hline Volatility of terms of trade & $\begin{array}{l}\text { Standard deviation of terms } \\
\text { of trade }\end{array}$ & $\begin{array}{l}\text { Banco de la República and } \\
\text { own calculations }\end{array}$ \\
\hline Corporate income tax rate & & DIAN \\
\hline FDI implicit profitability & Profitability/ stock of FDI & International Monetary Fund \\
\hline Interest rate differential & $\begin{array}{l}\text { FDI Implied returns - PRIME } \\
\text { rate }\end{array}$ & $\begin{array}{l}\text { International Monetary Fund, } \\
\text { Banco de la República and } \\
\text { own calculations }\end{array}$ \\
\hline Rule of law & $\begin{array}{l}\text { Index that fluctuates between } \\
-2,5 \text { (weak) and 2,5 (strong) }\end{array}$ & World Bank \\
\hline WTI petroleum price & & Datastream \\
\hline Trade openness & $\begin{array}{l}1 \text { if the company exports and/ } \\
\text { or imports goods and services }\end{array}$ & $\begin{array}{l}\text { Banco de la República and } \\
\text { own calculations }\end{array}$ \\
\hline
\end{tabular}




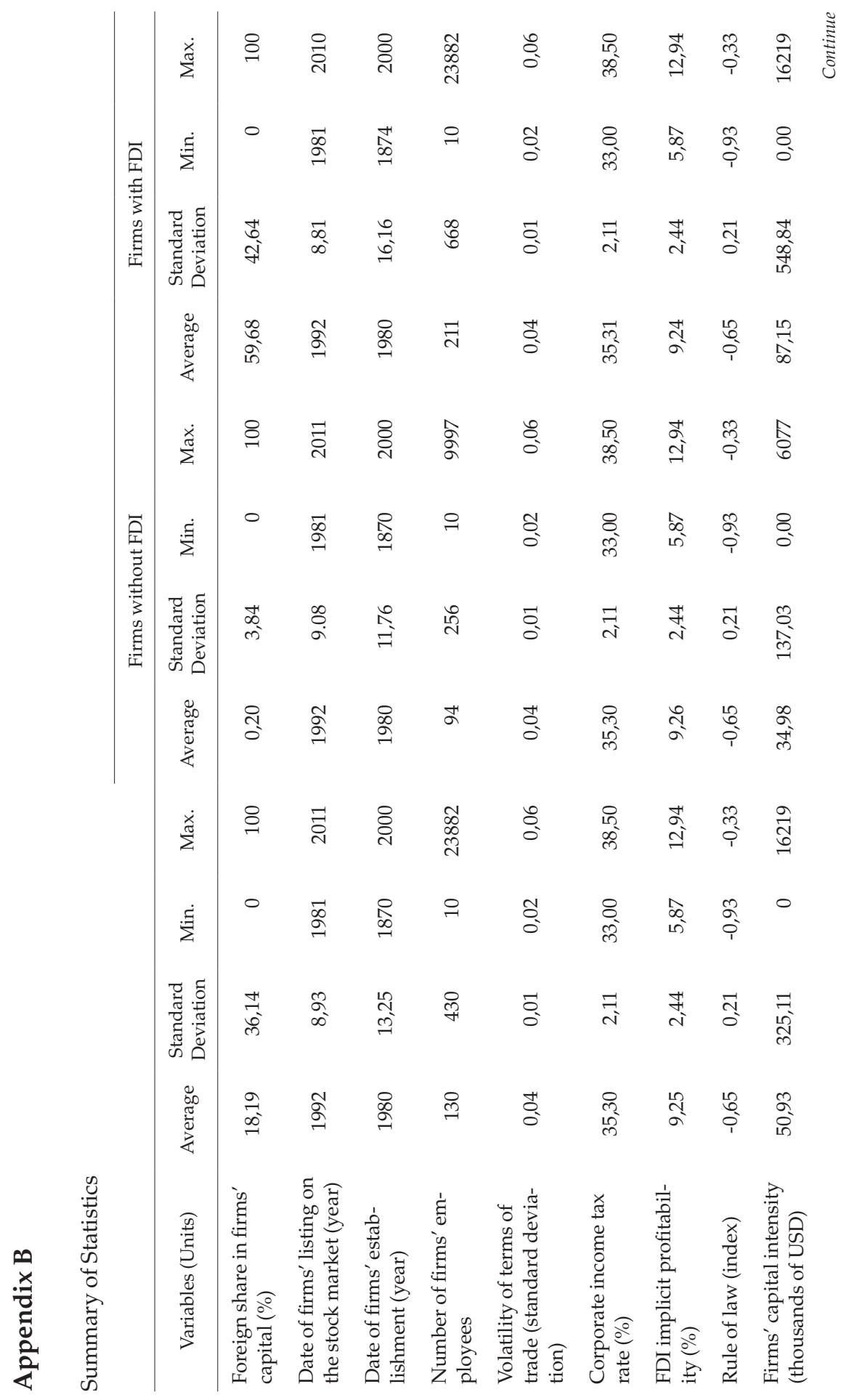




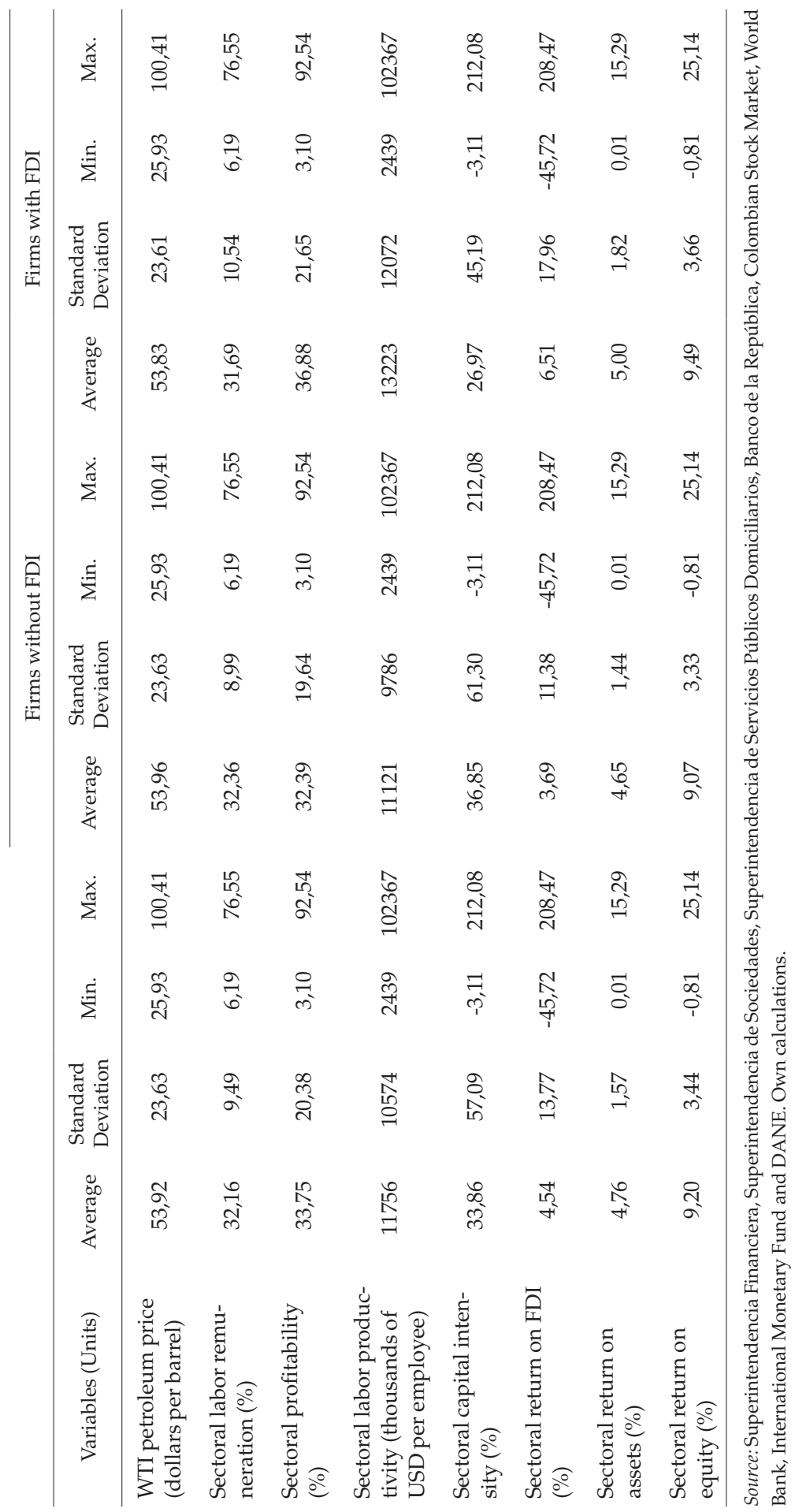


